Please do not remove this page

RMIT

UNIVERSITY

\title{
Bushfires are "men's business": The importance of gender and rural hegemonic masculinity
}

Tyler, Meagan; Fairbrother, Peter

https://researchrepository.rmit.edu.au/esploro/outputs/9921859046101341/filesAndLinks?institution=61RMIT_INST\&index=null

Tyler, M., \& Fairbrother, P. (2013). Bushfires are "men's business": The importance of gender and rural hegemonic masculinity. Journal of Rural Studies, 30, 110-119.

https://doi.org/10.1016/j.jrurstud.2013.01.002

Published Version: https://doi.org/10.1016/j.jrurstud.2013.01.002

Repository homepage: https://researchrepository.rmit.edu.au

(C) 2013 Elsevier Ltd

Downloaded On 2023/04/26 23:42:41 +1000

Please do not remove this page 
Thank you for downloading this document from the RMIT Research Repository.

The RMIT Research Repository is an open access database showcasing the research outputs of RMIT University researchers.

RMIT Research Repository: http://researchbank.rmit.edu.au/

\section{Citation:}

Tyler, M and Fairbrother, P 2013, 'Bushfires are "men's business": The importance of gender and rural hegemonic masculinity', Journal of Rural Studies, vol. 30, pp. 110-119.

See this record in the RMIT Research Repository at:

http://researchbank.rmit.edu.au/view/rmit:20220

Version: Accepted Manuscript

Copyright Statement: (c) 2013 Elsevier Ltd

Link to Published Version:

http://researchbank.rmit.edu.au/view/rmit:20220 
Bushfires are "Men's Business": The importance of gender and rural hegemonic masculinity

Dr Meagan Tyler (Victoria University) and Professor Peter Fairbrother (RMIT University)

\begin{abstract}
This paper offers a critical review of the international literature on gender, disaster and rural masculinities. Empirical reference is made to bushfires in Australia, offering new evidence from the State of Victoria. Bushfires loom large in the Australian imagination and there is an increasing amount of research now being conducted in relation to bushfire events. A significant gap remains, however, with regard to the issue of gender. Despite increasing evidence that gender plays a significant role with reference to disaster risk assessment, preparation and response, a gendered analysis of bushfire preparation and response has not been a sustained research priority. Building on the writing of others, a critical assessment is provided of the concept of a specifically Australian, rural hegemonic masculinity as a possible way of better understanding the social dimensions of gender, and bushfire preparation and response in the Australian context. This conceptual consideration is extended to draw attention to the process whereby alternative conceptions of masculinities may emerge. This recognition provides a basis for further research on gender and disaster internationally.
\end{abstract}

Keywords: gender, masculinity, bushfire, wildfire, Community Fireguard.

\title{
1. Gender and bushfire in Australia
}

Bushfires loom large in the Australian imagination. The Black Saturday fires, which occurred in the southern state of Victoria in early 2009, constituted one of the worst natural disasters in 
post-colonial Australian history. They also ranked as one the most deadly sets of wildfires the world has seen in the last 150 years (Cameron et al., 2009). Following Black Saturday, there has been significant public discussion in Australia about how best to understand the relationship between people, place and bushfires: how best to prepare for, communicate about, respond to and recover from these kinds of disaster events. One theme that has arisen focuses on gender in the context of bushfire. With the notable exception of an article published in this journal by Eriksen and colleagues (2010), there has been almost no published academic research the importance of the social construction of gender in relation to bushfire research and response.

The neglect of gender as an important element of Australian bushfire research is out of step with the growing international literature on gender and disaster, which seeks to better understand women in emergency situations (e.g. Enarson \& Chakrabarti, 2009; Enarson \& Morrow, 1998). Mirroring wider trends in gender and disaster research in (post)-industrialised nations, there is little consideration of the wider cultural construction of men's and women's gender roles and an understanding of gender as relational. Moreover, these sets of research tend to focus on specific case studies of discrete disaster events and "the individual woman" (Enarson, 2009, p. xvi). While there has been some attempt to make room for "women's voices" and consider women's experiences of bushfire in Australia (e.g. Cox, 1998), there has been almost no attempt to understand how this relates more broadly to the social construction of gender and the institutionalised inequality between men and women, particularly evident in rural areas.

The lack of gendered analysis in bushfire research is also striking given the evidence put forward by researchers in the field. While gender and gendered roles are often evident in the data, 
gender tends to remain invisible as an analytical category in much of the relevant literature. When surveying current bushfire research in Australia with a gendered analysis in mind, the critical importance of gender becomes quite clear. In the authors' own bushfire-related research, for example, gender has emerged as an important theme to analyse and explain, in its own right (e.g. Fairbrother et al., 2012; Tyler, 2012). What has emerged is that gender is everpresent in the narratives of those living in bushfire-prone locations, mostly rural areas and areas at the urban-rural interface. As will be discussed in section six, rural gender roles have consequences for bushfire risk perception, preparation, and response. In brief, men are seen as responsible for (quite literally) fighting the fire, while women are more likely to be found in caring and support roles, in particular, taking care of children. Perhaps as a result of this gendered division of labour, women are much more likely to favour evacuation as a response to a bushfire threat, while men are more likely to want to stay. While these trends can be found in evidence provided by previous research (e.g. Bolin et al., 1998; Mozumder, 2008; Scanlon et al., 1996), for the most part, no connections have been made to broader social construction of gender (c.f. Eriksen et al., 2010; Eriksen \& Gill, 2010), an omission which this article seeks to address.

\subsection{Bushfire in Australia}

A social constructionist approach to rurality (see: Bryant \& Pini, 2011) is used here to explore the ways in which people living in non-urban areas tend to understand their own circumstances. This approach allows for the recognition of the construction of "the rural" to include areas which may not, functionally speaking, be rural at all. Many authors have noted, for example, that notions of rural hegemonic masculinity as "real masculinity" still have influence in urban or 
peri-urban contexts (e.g. Hogg \& Carrington, 2006). Thus, social notions of rurality often extend beyond literal boundaries and conceptual definitions.

Understanding the relationship between hegemonic masculinity and bushfire means recognising that preparedness measures and dealing with bushfire events rely on stereotypically attributes (Connell and Messerschmidt, 2005). It must be noted, however, that such forms of masculinity are neither fixed nor static, including notions about heterosexuality, male-female relations and female dependency, homophobia, physicality and ideas associated with control and authority (Connell, 2005: 90). This concept of hegemonic masculinity is not straightforward and remains contested (see: Beasley, 2008; Flood, 2002; and McInnes, 2008). While seldom noted in relation to bushfire, Eriksen and others (2010) do use the concept to help explain the place and position of women in urban-rural interface landscapes, concluding that the practice of bushfire management as "men's business"' remains intact despite demographic and structural change which could be assumed to challenge such conceptions (p. 340). The strength of this analysis is that places the idea of hegemonic masculinity on the conceptual framework for considering gender and bushfire but it is limited in that the analysis rests on a relatively fixed view of gender relations rather than masculinities per se. Paradoxically, even where analysis recognises the contestability and tenuousness of masculinities the focus still tends to be on the sustenance of hegemonic masculinity, and the maintenance of boundaries, rather than their disaggregation. While the focus on boundary maintenance is critically important, the possibility of disaggregation and fracture (and resistance) is equally valuable. Hence, while opening up an important dimension in relation to gender and bushfire, it is also necessary to question the complexity of the construction of hegemonic masculinity as well as the processes for realising alternative masculinities. 
In order to fully understand the background to the data and arguments presented here, the Black Saturday fires, and the policy context that was in place at the time of the fires, must be taken into account (see Teague et al., 2010). With the events of Black Saturday, which occurred the year before the project interviews took place, there was a heightened public awareness of the prepare, stay-and-defend or leave-early (often shortened to "stay or go") policy which had been adopted by most Australian rural fire agencies. This policy, which Community Fireguard (CFG) programs (educational awareness) promoted, encouraged families to choose between evacuating well before the fire threat reached their homes, or to prepare their homes and plan to "defend" them against an oncoming bushfire (Fairbrother et al., 2010; Tibbits \& Whittaker, 2007). There was a sturdy belief among governments, fire agencies and many researchers prior to Black Saturday (e.g. Handmer \& Tibbits, 2005; ; Tibbits \& Whittaker, 2007), that staying to defend, was often the safest option, epitomised by the slogan: "People save houses, houses save people" (Rush, 2009, p. 15). This is in contrast to most of North America, for example, where voluntary and forced evacuation is the most common policy approach to wildfire (McCaffrey \& Rhodes, 2009). It is contended here that the preference for "staying to defend" prior to Black Saturday may be related to dominant constructions of rural hegemonic masculinity. It may also help to explain why, unlike disasters worldwide where women are usually over-represented in death-toll statistics (Enarson \& Chakrabarti, 2009), men are overrepresented in death-toll statistics in Australian bushfire events (Haynes et al., 2010).

\subsection{Gender: A neglected area of research}


There is a significant gap in terms of a social constructionist approach to gender in the literature on bushfire in Australia. In the rare instances when women are specifically mentioned, there can be a tendency to essentialise gender rather than acknowledging the changing constructions of masculinity, femininity, and gender roles. As a result, when gender is mentioned in bushfire research, it is often only as a superficial category rather than as an important element of the overarching framework of analysis. For example, in a study of bushfire fatalities in Australia between 1900 and 2008, Haynes and others (2010) found that men were significantly more likely than women to die during a bushfire event. Gender was clearly an object of the analysis and indeed the authors gesture towards men's increased likelihood to actively defend a house during a fire while women are more likely to "shelter passively", but this provides no indication of why such gendered differences occur.

Indeed, the gender differences in death rates may not appear to be particularly critical when seen in isolation. Compared with the international literature on gender and disaster, however, the data from Haynes and colleagues (2010), displays an unusual and significant trend. It is widely recognised in gender and disaster literature that women are generally more vulnerable to the effects of disaster and that, furthermore, women tend to be over-represented in deathtoll statistics (Enarson \& Chakrabarti, 2009). Following the Asian tsunami in 2004, for instance, women made up as much as 80 per cent of the dead in certain parts of Indonesia, India and Sri Lanka (Ariyabandu, 2009). The problem is also evident in more industrialised countries. In Japan, for instance, women, particularly socially marginalised women such as single mothers, are more likely than men to be injured or killed during earthquakes (Masai et al., 2009). The higher death tolls for women can be due to a range of factors, including gendered restrictions on movement in public, dress codes, access to information and child-caring responsibilities but also as a result 
of the material consequences of gender inequality and social marginalisation (Ernarson and Morrow, 1998). In brief, women are less likely to hear or understand official disaster warnings, less likely to be able to act freely on official (or informal) warnings but are more likely to feel responsible for the care of others, particularly children, the sick and the elderly (Fothergill, 1998).

It is unlikely that the factors leading to women's increased vulnerability in disasters globally, are completely absent in the Australian context. Rather a particular construction of hegemonic masculinity in rural areas of Australia may help to explain why men are over-represented in bushfire death-toll statistics. What is therefore required to more fully understand bushfire and gender in the Australian context, is the importance of gendered roles for women and men, as well as the influence of constructions of hegemonic rural masculinity. While there are alternative masculinities that are also worthy of investigation, this research is framed within an understanding of the prominence of hegemonic masculinity which was borne out in our interview data as well as pre-existing research by others (developed in section four). Each of these areas will be considered in the following sections of the paper.

\section{The gendered context of bushfire and rural living}

An understanding of the gendered dynamics of rural living is particularly important in the Australian context as bushfires are largely constructed as being "men's business" (Poiner, 1990). Research on rural masculinities and gendered power relations in rural areas suggests that "rural life is typically highly patriarchal" (Campbell et al., 2006, p. 5) and that there is often a particularly clear divide between men's and women's roles and activities in rural settings (Pini, 
2006, p. 401). Rural Australia is certainly no exception to this observation (Alston, 2005;

Dempsey, 1992; Eriksen et al., 2010; Poiner, 1990). The gender segregation in rural living is also mirrored in emergency management and bushfire-fighting, areas that are especially masculinised and often exclude women (Cox, 1998; Robertson, 1998). Despite recognition that emergency management and fire-fighting are militarised and male-dominated institutions (Baigent, 2005; Fordham \& Ketteridge, 1998; Poiner, 1990; Robertson, 1998; Scanlon, 1998), an understanding of this gendered context is still largely lacking in research on bushfire and bushfire responses in Australia.

Gretchen Poiner (1990), in her ethnography of Marulan in rural New South Wales, - one of the most prominent and oft-quoted works on gender roles in rural Australia - notes the especially conservative nature of rural living in Australia. Poiner states that although there may appear to be little difference between urban and rural dwellers, the critical point of divergence is that people living in the country identify as "country people" and "subscribe strongly to the rural ideology" which she describes as leaning "heavily on acceptance of both the family in its conservative form and male domination" (p. 136). Women are therefore faced with significant inequalities in both their domestic (family) life and public life in rural areas. In more recent work, Alston (2005) has continued this line of argument, explaining the way in which the private household division of labour as well as the issue of male-dominated public space in rural areas are still largely shaped "within the constraints and expectations of the gender order of women's subordination" (p. 141).

In terms of public inequalities, previous work on gender and local government in Australia has shown "the way in which traditional and conservative views about gender that are dominant in 
rural towns, make participation in public leadership problematic for women" (Pini, 2006, p. 398). Dempsey (1992) and Poiner (1990) both suggest that this problem is twofold. Firstly, traditional gender roles provide men with a seemingly "natural authority", positioning them as the decision makers and thus placing women at a disadvantage if and when they try to prove their credentials for leadership positions. Secondly, traditional gender roles require women to provide considerable material and emotional support for their families, a situation which often leaves them with little time to further contribute at the level of formal governance. Both of these elements have been proven as relevant to research on gender and bushfires. For example, the construction of men as the preferred "decision makers" is likely to give a heavily gendered dimension to household bushfire safety plans and the ultimate decision to evacuate or stay and defend the house during a bushfire event and there is certainly some evidence for this in existing research (e.g. Eriksen et al., 2010; Proudley, 2008; Goodman \& Proudley, 2008;). The common relegation of women to the domestic sphere is also likely to influence the gendered make up of rural voluntary fire-fighting organisations, which Australia relies heavily upon during bushfire emergencies (Beaston \& McLennan, 2005).

While women may experience forms of exclusion from various masculinised, public-sphere activities, they also experience disadvantage within the domestic sphere and the power dynamics of the family. Traditional gender roles, arguably more entrenched in the rural context (Alston, 1995, 2006; Hogg \& Carrington, 2006; Poiner, 1990), result in women bearing an exaggerated double burden. Women frequently take on "men's work" (traditionally paid work, but in a rural context this may involve work outdoors, or helping on the farm etc.). It remains rare for men, in return, to take an equivalent share of "women's work", especially domestic chores and child-rearing (Beaujot \& Liu, 2005; Poiner, 1990; Väänänen et al., 2004; Zenaida et 
al., 2005). Poiner (1990) also notes that the decision making process in families, and within couples, in rural areas is male dominated. She does speak of finding some notable exceptions to this in her ethnographic work, however, instances where women had a greater say in decision making. Such examples were in realms deemed relatively insignificant and "feminine" by men; areas, such as "purchases of household appliances, furniture and furnishings" (p. 155).

Recent studies continue to emphasise themes of male dominance and unequal gender relations in rural settings, despite the significant changes that have occurred in rural Australia over the last two decades. Many scholars point to social changes wrought by economic restructuring (e.g. Carrington \& Scott, 2008; Hogg \& Carrington, 2006; Pease, 2010) or prolonged drought (Alston, 2006), for example, in forcing women out of the (often agriculturally-based) home and into the paid workforce. Such moves undoubtedly also cause changes in understandings of gender norms and roles. However, as Alston (2005) and Hogg and Carrington (2006) also point out, many of the ideals surrounding masculinity and male dominance have remained relatively steadfast. Male privilege, the over-representation of men in both formal and informal public bodies, as well as the links between, power, decision making and masculinity are often highlighted as part of an ongoing and sometimes stark inequality between men and women in rural settings (e.g. Hogg \& Carrington, 2006; Pini, 2006; Shortall, 2006; Wendt, 2009). This ongoing inequality does not mean, of course, that women never manage to rise to positions of authority within rural communities, or that there are no households where women are the primary decisions makers. Rather, the available research suggests that gendered norms in rural areas make for a particularly uneven playing field. As Alston (2005) explains, it is not that the "rural crisis" has not challenged traditional concepts of patriarchy or that women have not found various forms of resistance, but rather that "for those committed to remaining in rural 
areas, hegemonic masculinity still dominates and constrains gender relations...That masculine hegemony can be so overwhelming and yet go so unremarked indicates a particular blindness to the lived experience of many rural dwellers" (p. 143, 156).

The problem should therefore be extended so that the mutability of hegemonic masculinity is unravelled and made visible. Central to the stereotype of masculinity and bushfire in Australia is the view that women are the potential victims of bushfire and therefore should be protected by men and the agencies. Eriksen and colleagues (2010) note there appears to be solidity in the masculine hegemonic archetype that suggests a diffuse strategy to tackle the implications of the model, with communication and education at the centre. However, the analysis can be taken further to consider the bases for alternative masculinities emerging in the rural localities that define much of the Australian landscape. That is, there is a need to recognise that cultural change requires more than a change in educational or communication strategies from fire agencies. The starting point of such an analysis is that there are a range of gendered dimensions at play in the modern rural landscape. First, traditional gender roles underwrite a specific cultural understanding and mode of decision-making where men and masculinity seem to prevail. Second, and qualifying the first point, these roles are not fixed and there is evidence that some men and women no longer accept or subscribe to them, at least in relation to everyday activity (e.g. Carrington \& Scott, 2008; Hogg \& Carrington, 2006; Pease, 2010). Thus, while uneven, and not always visible, a subterranean process of reassessment may be in process, reflected in the ways that some women are taking steps to assert themselves in traditional settings as well as the way men may be beginning to reassess the negative aspects of hegemonic masculinity. In relation to bushfire, the very experience of these events may actually stimulate a reassessment by men and women of their gendered roles (WHGNE, 2011). 


\section{Making masculinities visible}

Understanding the gendered dynamics of rural living must involve a consideration of both women's and men's roles. While focusing on women is certainly important, particularly when trying to highlight how women have been marginalised or excluded from analysis, it is also important to avoid holding women up as "the other" to a supposedly objective but implicitly male / masculine standard of normality. As many scholars writing in the area of masculinity studies have pointed out, norms are often based on a male standard but the male aspect of the norm generally remains invisible (Campbell et al., 2006; Campbell \& Bell, 2000). Thus, what men do becomes held up as the universal norm. As Campbell and Bell explain in "The Question of Rural Masculinities" (2000), masculinity is generally a "generic, unmarked category of power" and, as a result, masculinity remains invisible "while femininity is continually marked for special emphasis" (p. 536). The need to consider the construction of masculinities is also intertwined with the understanding that gender is relational, that is, gender roles are constructed in relation to each other rather than existing autonomously. Campbell (2006) explains this aspect further by stating that: "rural masculinity is equally an aspect of the lives of men and women...The way rural men conduct their lives has a huge impact on how rural women live their lives, for gender is a relational matter" (p. 2). It is therefore important to make masculinity visible and to look at both the construction of both masculinity and femininity when considering the impact of gender.

The "invisibility of masculinity" problem is certainly evident in some of the existing research on bushfire that mentions gender. One of the most prominent examples of this is the 
representation of women's preference for evacuation as irrational or ill-informed (e.g. Beringer, 2000; DeLaine et al., 2008). When considered in isolation this representation may seem plausible; women often proclaim to know little about fighting bushfires and therefore may be more prone to unfounded fears about a bushfire threat. However, women's preferences are not judged on the basis of an objective analysis of the threat but rather tend to be judged on the basis of a comparison with men's assumed "rational" and "informed" preference for staying to defend a house (e.g. DeLaine et al., 2008). Indeed, studies on risk perception have shown that white men are likely to rank a variety of risks significantly lower than women and minority groups (e.g. Finucane et al., 2000). Further, it has been theorised that this difference is due to socio-political factors rather than a lack of understanding or education among minority groups and women (e.g. Bateman \& Edwards, 2002; Finucane et al., 2000; Gustafson, 1998).

Both policy and practice for bushfire responses in Australia are assumed to have emanated from objective and empirical, if not scientific, bases but this does not take into account the fact that emergency management, bushfire response and fire-fighting, remain overwhelmingly male dominated areas (Beaston, 2008; Beaston \& McLennan, 2005; Eriksen et al., 2010; Poiner, 1990; Robertson, 1998). Women make up less than a quarter of all rural fire volunteers in Australia and the vast majority of these volunteers are placed in non-operational or support / administrative roles (Beaston and McLennan, 2005).

Furthermore, while the areas of emergency management and rural fire-fighting may be materially dominated by men, they are also culturally masculinised (Eriksen et al., 2010; Poiner, 1990). In this respect, they are associated with traditionally masculine attributes and are likely to exclude women. The area of emergency management, for example, has been described by 
Robertson (1998), as being: "[b]y tradition if not by right, a male prerogative in Australia. Emergency services organisations, so similar in nature and activity to the military, were regarded as very much a male domain" (p. 201). Emergency and disaster management organisations are often highlighted as having military-based histories and continuing to maintain a militaristic, "command and control" style of operation (Fordham \& Ketteridge, 1998). This is an important point as the military is a particularly prominent site for the construction and reproduction of hegemonic masculinity (Agostino, 2003). Moreover, masculinity and the exclusion of women are embedded in the institutional culture of military organisations (Connell, 2003; Enloe, 1983). Given the masculinised and militarised nature of emergency management and disaster response it is misleading to consider them through a gender-neutral lens; they must be understood as heavily intertwined with dominant constructions of masculinity.

Fire-fighting and especially bushfire-fighting in rural areas are likely to fit at the more extreme end of the militarised / masculinised emergency services organisations. Fire-fighting is "by any measure...a male dominated occupation" and "[c]ulturally speaking, the work of fire-fighting is extremely masculinised" (Baigent, 2005, p. 45). It is not only that fire-fighting is associated with traditional characteristics of masculinity, such as physical strength, mateship, courage and aggression (Maleta, 2009), but that the concept of fire-fighting is seen as so inextricably linked with men that "the notion of women fighting fires still does not fit into society's picture of firefighting" (Baigent, 2005, p. 60). The aspect of militarisation in fire-fighting is especially clear in relation to bushfire-fighting in Australia. Militarisation is not only evident in the history and structure of rural volunteer fire services such as the Country Fire Authority (CFA) (Murray \& White, 1995) but also in the cultural representations of bushfire-fighting. With reference to the Ash Wednesday fires in South Australia and Victoria in 1983, for example, Cox (1998) explains 
that: "[i]mages of war and the ANZAC spirit are replete in media accounts of the fire, which has a front, and armies of volunteers, mostly young men, who battle the flames in a 'spirit of mateship and defiance'" (p. 132). Despite the strikingly masculinised nature of bushfire-fighting, its importance for constructing and recreating gender roles in Australia is "rarely discussed" and gender-blind policy still dominates (Eriksen et al., 2010, p. 2). This neglect is mirrored in the (unacknowledged) gendered nature of bushfire related policy in Australia.

\section{Rural hegemonic masculinity and bushfire in Australia}

If official approaches to bushfire are likely to rest on an unacknowledged male standard, it is important to consider the relationship between approaches to bushfire safety and the social construction of masculinities, in particular, rural masculinities. The now widely employed concept of hegemonic masculinity, expounded by Connell (1995), is employed here. As the fields of gender and masculinity studies have evolved, there has been a shift away from talking about "masculinity" to "masculinities" (Campbell \& Bell, 2000; Donaldson \& Tomsen, 2003). While this may add nuance and complexity overall, applying the concept of multiple masculinities may not be helpful when seeking to analyse dominant cultural constructions of masculinity specifically. Connell's concept of hegemonic masculinity (1995) is particularly useful, therefore, as it acknowledges that there is not only one construction of the masculine but it also highlights that in any set of gender relations some constructions of masculinity have more cultural weight than others. Connell (2003) states that hegemonic masculinity is "the most honoured or desired...it is connected with prominent institutions and cultural forms, such as business and sport, and is extensively promoted in the mass media" (p. 15). Campbell and Bell (2000) expand on Connell's original understanding and state that "[h]egemonic masculinity is therefore the version of 
masculinity that is considered legitimate, 'natural' or unquestionable..." (p. 535). With increasing scholarship in the field of rural studies, the concept of a hegemonic masculinity specific to the rural context has also been put forward (Campbell \& Bell, 2000; Campbell et al., 2006; Carrington \& Scott, 2008). There has also been an increasing recognition of needing to understand context-specific constructions of hegemonic masculinity. Pease (2001), for example, writes that: "[w]hile there are benefits in generalizing about western masculinities, such writing misses the uniqueness of the lived experiences of Australian men" (p. 191). Three main characteristics emerge which are central to what could be termed Australian hegemonic rural masculinity: the frontier mentality and the idea of (colonial) man against nature, the importance of physical strength, and the valorisation of risk taking. These aspects can all be seen as important in relation to the context of bushfires and bushfire safety and each will be discussed in turn.

\subsection{The frontier mentality}

The history of colonialism and the existence of a "frontier mentality" are important when attempting to understand dominant constructions of Australian masculinity (Connell, 2003; Pease, 2001). Colonial or frontier masculinities are not only evident in settler societies but are often revered. As Carrington and Scott argue: "[i]n frontier societies such as Australia...exploitation and colonization allowed for the development of the idea of specific 'frontier' masculinities, which achieved their own kind of symbolic ascendancy in colonial societies" (Carrington \& Scott, 2008, p. 650). The most prominent aspect of this colonial / frontier masculinity is a fight against and desire to control nature. Carrington and Scott (2008) state that the "real strength" of rural men is taken to be "their ability to control the 
environment rather than being controlled by it" (p. 650). This feature of rural hegemonic masculinity fits well with the construction of men's roles during bushfires and the overall construction of bushfires as "men's business". Hence, if "real men" are supposed to fight and control nature it is not surprising that fighting bushfires is seen as a male domain and that men are more likely to "stay and defend" during a bushfire threat than women. This may also help to explain the prestige which is afforded to those that fight bushfires. Poiner (1990) notes that men's work in fighting bushfires is held in especially high-esteem, certainly much higher than the "auxiliary" roles assigned to women during bushfire threats. She explains that this social appreciation afforded to men is important in maintaining rigid gender roles in rural communities (p. 181) and it can also be seen as reinforcing hegemonic rural masculinity.

\subsection{Physical strength}

Physical strength is commonly linked to concepts of hegemonic masculinity and especially rural masculinity (Carrington \& Scott, 2008; Poiner, 1990). The importance of physical strength in constructions of rural hegemonic masculinity is also often related to the idealisation of controlling nature. Carrington and Scott (2008) give the example of the valorised "rural warrior hero" who is constructed as a man "who can exert physical force to survive in extreme environmental conditions and harsh landscapes" (p. 653). Gender is relational, however, so it is not only that men should possess these characteristics, but that women should not, or cannot. In relation to bushfires in rural Australia. Poiner (1990), for example, states:

Everyone knows and accepts the reason [that women cannot fight fires]: the task is challenging and strenuous, one requiring strength, stamina, grit and guts, qualities 
which are stereotypically male, and therefore antithetically exclusive of females ( $p$.

172).

This binary construction of men's and women's abilities may help to explain the continuing exclusion of women from bushfire-fighting organisations as well as the continuing prominence of the image of the "rural warrior"; the heroic, strong man, battling nature to save his home and family. Following the Black Saturday bushfires in Victoria, for example, journalist Greg Sheridan (2009) wrote in The Australian newspaper, that: "[t]hey breed them tough in the Australian bush...none tougher than the men, who fight like tigers to save their homes until it's too late, and then fight to save their families...". The problem with this representation, however, is that it obscures the fact that that the very act of "fighting like tigers until it's too late" can be a contributing factor to putting a family in danger in the first place. As the Black Saturday fires made abundantly clear, the decision to stay and fight rather than evacuate is inherently dangerous and can be deadly (Handmer et al., 2010). In the construction of the "rural warrior" taking this risk, if it is indeed acknowledged as a risk, is often celebrated rather than decried.

\subsection{Risk taking}

Risk-taking is also a prominent aspect of Western masculinities (Meier-Pesti \& Penz, 2008) and may be especially important in rural contexts. Campbell and others (2006) note, for example, that rural men take more risks when compared with urban men, and that this is "perhaps in part, because of a tough-guy vision of masculinity..." (p. 7). They also add that this sort of risktaking leads men to neglect their own well-being and health, citing the example of refusing to wear sunscreen lotion when exposed to the sun, even when aware of the risks. This behaviour, on one level, appears almost irrational, as it is not that men are not aware that they are putting 
themselves at risk. Indeed, the act is made all the more masculine by the fact that it is known to be risky (Campbell et al., 2006). lacuone (2005) noted similar attitudes regarding masculinity and occupational health and safety in the Australian construction industry: that actively seeking to maintain personal safety is seen as weak and feminised while actively seeking risky or dangerous situations is seen as strong and manly. In this context, risk-taking is actually emphasised as a positive, it proves that a man is a "real man", by conforming to standards of hegemonic masculinity.

The parallels between norms of rural hegemonic masculinity and bushfire-fighting are striking. Fighting a bushfire is a risky activity; it is also promoted as a heroic and masculine activity. Defending a home and fighting a fire necessitate facing risk, using physical strength and controlling (or at least attempting to control) nature; all elements of rural hegemonic masculinity. The links between hegemonic masculinity and staying to defend a house in a bushfire may seriously influence decision making. Leaving or evacuating may then be culturally seen as weak or feminised (Griffiths, 2012) in an environment where being weak and feminine is definitely at the lower end of the pecking order (Connell, 2003; Dempsey, 1992; Poiner, 1990). Staying to defend, therefore, can be seen as becoming socially elevated to a position above leaving, to a point where it may be represented or understood as the "correct" or "right" decision. As history professor Tom Griffith's recently wrote in his scathing critique of the public response to Black Saturday: "[w]e all have to learn better when to retreat - and we have to find a word other than 'retreat'”' (Griffiths, 2012, p. 53).

The consequences for men of living up to these standards of hegemonic masculinity in relation to bushfire events, raises the importance of alternative masculinities. Choosing to "stay and 
defend", for example, means that some men are left alone in a house to fight the oncoming bushfire after other family members have evacuated. Given that the experience of living through a bushfire has been found to be significantly traumatic for most survivors (Laugharne et al., 2011; McFarlane et al., 1997) it is likely that these men develop particular coping strategies to deal with both the experience of fighting the bushfire and its aftermath. It may be difficult, however, for men to speak out about this experience. The public valorisation of staying to defend in Australia, mixed with norms surrounding masculinity and emotion, are likely to limit many men's ability to express fear or trauma that has been suffered during the process (see: WHGNE, 2011). Therefore, there are likely to be gendered issues surrounding the psychological impacts of bushfire and the associated recovery process, which also require investigation.

\section{Methodology}

In 2009 and 2010, a series of interviews ( $n=47)$ and focus groups $(n=6)$ were conducted with staff from the Country Fire Authority (CFA), and residents of rural and regional areas involved in the Community Fireguard (CFG) program. A total of 30 CFA staff and CFG facilitators were interviewed and 46 residents (all CFG members) participated in the focus groups. The CFA is a volunteer organisation which is responsible for fire-fighting in rural and regional areas within the State of Victoria. It is also involved in community awareness, education and safety programs and fire prevention activities. The CFG program is one form of community outreach that involves CFA volunteers. It is a community development initiative that aims to "encourage community and individual self-reliance for bushfire preparedness" (Fairbrother et al., 2010) and centres around facilitated sessions, often conducted at residents' homes, with the ultimate outcome of producing a household bushfire survival plan. 
The CFA staff and CFG participants were interviewed about attitudes towards bushfire and bushfire preparedness in semi-structured interviews and focus groups, averaging about an hour per interview. The interviews were conducted in a number of areas (divided by CFA boundaries) across Victoria: Barwon South West, Loddon Mallee, Hume, Gippsland, Southern Metro (Westernport), Northern and Western Metro, Eastern Metro (Yarra) and Grampians. Despite the names, none of the regions are actually in the metropolitan area of Victoria's capital city; Melbourne. Some of these CFA districts do cover localities at the urban-rural interface, but the majority are rural and regional areas (see diagram 1).

The interview data was initially analysed in relation to a CFA commissioned and funded project on the strengths and failures of the CFG programs, in particular an assessment of the appropriateness and relevance of training packages, consistency of messages across localities, community members' understanding of key messages and the importance of the role of facilitators. In reading and coding the transcripts for this project, however, the importance of gender became noticeable. Gendered language was often employed and, reflecting the international literature on gender and disaster, there were differences in the way that many men and women spoke about preparedness and response to emergency events. To borrow the words of Eriksen and colleagues (2010), gender stuck out in many interviews "like a beacon." Several instances of this occurrence are explored in more depth in the following section.

\section{Risk perception, preparedness and response: How gender matters}


The international literature on gender and disaster suggests that, mostly as a result of the social construction of gender roles and gendered care-giving responsibilities, women are more likely than men to be risk-averse (e.g. Bateman \& Edwards, 2002; Enarson, 2009; Tierney, 2006). A number of the interviewees in heterosexual relationships (all participants who mentioned a spouse intimated or explicitly said their partner was of the opposite sex) mentioned that there were planned differences in approach between themselves and their partner. Some women simply stated that they, or their female neighbours or friends, planned to leave the area if there was a bushfire threat and take their children, leaving their male partners to "stay and defend". Comments such as "she'll go with the baby and he'll stay" or "I've said [to my husband] I am not staying this year, each year we will reassess depending on where our kids are at" were repeated by ten interviewees. Eleven participants also recounted more sudden disagreements or differences of opinion between themselves and their spouse in relation to risk perception, preparedness and response to a bushfire event. In all of the documented instances of disagreements between spouses, women were more risk averse, wanting to do more to prepare and wanting to evacuate (often with children), rather than "stay and defend".

These differences could appear in relatively small ways, such as preparing the house and surrounding area in preparation for a bushfire season. As one man mentioned in a CFG focus group interview, for example: “My wife and I don't agree on how much vegetation should go. She wants it pretty denuded." Other instances of disagreements were more dramatic. One CFG co-ordinator, recalled a disagreement between a couple in the local CFG group:

We called in on the one Community Group and the one lady said "Oh look the only warning we had was the jet roar, just that sound of jet coming over the mountains and I said to my husband 
'we need to get ready' and he's said 'don't be stupid I can't see any flames or anything'”'...and she said within probably 10 or 15 minutes it was there...

This scenario is similar to a number that were recounted at the Black Saturday Royal Commission where there was evidence (through phone conversations, text messages and so on) that in several cases individuals, couples and whole families died as a result of this kind of disagreement between spouses (Handmer et al., 2010). In all recorded instances, the male partner wanted to stay and the female partner wanted to evacuate (Handmer et al., 2010). Similar stories have also been recently recorded in the Beating The Flames: Women escaping and surviving Black Saturday report (WHGNE, 2011). Perhaps the most telling part of the report, however, is the authors' introduction, which thanks many women for sharing their stories but also laments the loss of others:

Sadly, some women were silenced by our society's imperative to protect the myth of masculinity. They felt the need to protect the man they love by not allowing their initial accounts of his actions to be published. For others, their retraction was due to fear of repercussions from that man (WHGNE, 2011, p. 1).

It must be understood that in such a context, explicit discussion of gender roles can be difficult. These conditions may also mask men's experiences and the existence of alternative masculinities.

In the research outlined here, differences in gendered expectations were often not consciously spoken of, but rather became an inadvertent part of a wider dialogue about community preparedness. One woman, for example, mentioned that, through discussion and CFG training, 
she had managed to convince her husband that staying to defend was not the right option for them: "He won't admit that but I believe that he was always going to stand on his roof with a hose but after a lot of discussions with Tom [pseudonym]...yes he has changed his mind." This quotation highlights an important theme to emerge from the interviews and focus groups; that staying to defend seemed heavily tied up (at least for some men) with a sense of masculinity. The man standing alone on his roof with a hose fighting the fire sounds remarkably like the dominant cultural narratives about rural hegemonic masculinity; man against nature, shows of physical strength and risk-taking.

Other women mentioned that they had acquiesced to their male partner's wishes to stay and fight the fire. A female CFG member, for instance, commented that: "My partner has always wanted to stay and defend and l've always really, not so comfortable but yeah, ok l'll do it but I'm slightly asthmatic, I don't do well in the heat and emotionally I don't think I'm prepared to stay." Despite these misgivings, she agreed to stay and defend the house with her male partner.

A number of women mentioned significant pressure to stay and defend, and even that there were social repercussions for choosing to evacuate. In one example, a CFG facilitator recounted how a woman, new to the local area, wanted to evacuate with her young child if there was a bushfire threat when her husband was away from home:

[T] hen when we did have a fire and I knew she'd be nervous....because she had a younger child and was pregnant...so she was going to [go] and then she said 'Oh, I don't know, should I be leaving or not?' I said, 'If you think you should be leaving, well go now'. And, she had parents to go to - in another location - so anyway she put her husband's trailer on the back...and then went with her child. And when the husband came home from the fire, be absolutely gave her a caning 
[a telling off] - at no time was it threatening - you know, this is the worst day for umpteen years, and because they had put the fire out, you know, he gave her a caning. I said: 'No, she made the right decision'.

Presumably in this account the husband in question did not literally give his wife a "caning", (the facilitator stresses it was not threatening) but the language he uses to describe what happened indicates it was, at least, verbally threatening. The husband was reportedly very angry that his wife had, while pregnant and caring for a small child, decided to evacuate.

From an outsider's perspective this is likely to appear odd, if not inappropriate, behaviour. The CFG facilitator, however, tries to explain it in the context of the social pressure to stay and defend: "if somebody has said they want to leave early, they've almost been howled down. It's sort of, don't be a wuss [coward], of course you'd stay." It is as though there was shame attached to evacuation, not only for men who may be seen as "unmanly" or not living up to standards of hegemonic masculinity but also for failing to protect their wives and children. If a woman has to evacuate, it shows her husband was not there to "look after" her at the time of the fire.

The masculinised concept of "stay and defend" is therefore often held up in contrast to "leaving early" which is often associated with cowardice (as above) or with femininity and fear. One CFG participant, for example, described two women who were part of his community group as "hysterical" - a notoriously loaded term - for not wanting to "contemplate staying":

[A]nd the last two, both women of the partnership, went hysterical when they heard about the fire thing and they didn't want to be a part of it [staying to defend] and they didn't want their husbands to be a part of it...They could not contemplate staying at the coast in a fire. 
These scenarios also gesture towards the inequality of rural gender roles in Australia where men are seen as the primary or more rational decision makers (Dempsey 1992, Poiner, 1990). This sentiment is especially true in the context of bushfire, which remains largely constructed as men's business (Eriksen et al., 2010). These attitudes may filter into the perception that a man's preference to stay and fight the fire should take precedence over, or be seen as inherently more rational, than a woman's "hysterical" preference for evacuation.

In other instances, female interviewees cited practical reasons as to why their husbands wanted them to "stay and defend". One participant in the community focus groups, for example, stated that she had watched a DVD provided by a rural fire agency on what to expect when staying home during a bushfire and that this had prompted her to defend the house. She stated: "that's [the DVD] what gave me the confidence to stay home...that was a fairly strong message, the safest place is your home, like don't run away" but also elaborated further by adding: "plus my husband was wanting me to stay because he didn't want to lose his shed and all that."

Undoubtedly, some women felt significant pressure, either through the messages promoted by community groups and fire agencies prior to Black Saturday, or directly from their husbands to stay and defend even if they had serious concerns about this course of action. Again, this fits with the literature on the invisible male standard, where "staying to defend", a typically masculinised activity in Australia, is taken to be the ideal norm that women must be trained into accepting. The tendency for women to want to evacuate is not taken as seriously and those who do plan to "leave early" were seen as being "wussy", cowardly or weak; feminised characteristics, the very antithesis of hegemonic masculinity. 
Hegemonic masculinity is not immutable, however, and attitudes and dominant messages can and do change. In the post-Black Saturday context, a number of participants mentioned that the pressure to "stay and defend" had eased and there was greater acceptance of the choice to evacuate or "leave early". When asked about key messages to residents, one CFG facilitator replied:

Leave, leave early. Not all houses are defendable under some circumstances...The fact that - well we never alluded to before - but the fact that they may - there is risk involved in staying and defending. Because we never discussed that.

A participant in the community focus groups noted similarly, that:

I mean the message going out was that it's okay to go now. That's the main thing because the line - well the way I understand it anyway - the line that was sort of pushed in the past was stay and defend. But that's all changed now after February 7 [Black Saturday].

While another participant, stated:

Yes, before I think the message was you can stay and defend, you can defend this house...this is what you do, you prepare, you be ready. This is what you do, you have your buckets of water around in strategic places and you can defend...We've seen that that's not always the case. We've changed our minds. 
While all three interviewees mention that leaving early is an option, they also state that this is a noticeable change and that there was a previous push to emphasise "stay and defend". Moreover, the facilitator says that the risks of staying were not fully acknowledged. It is only now, after the significant loss of life resulting from Black Saturday, that residents can voluntarily evacuate without being worried about accusations of cowardice. Hopefully such changes in policy may also be able to create cultural change in terms of decision making, hegemonic masculinity and the associated pressure to stay and fight the fire.

Gender roles are not static or immutable, so such changes can have an impact when it comes to constructing acceptable "masculine" norms. Indeed, future research may be improved by a consideration of alternative (i.e. non-hegemonic) constructions of masculinity, which are less likely to put men and women at risk in disaster events such as bushfire. This observation draws attention to multiple or alternative masculinities and the ways these conceptions may be part of the process of change that is and could take place. As demonstrated, hegemonic masculinity is a particular archetype that is not ever fully embodied by individual men. For Eriksen and colleagues (2010) this construction of masculinity could be challenged by education. While this may be so, it is importance to recognise the overarching cultural and structural nature of constructions of hegemonic masculinity that already exist and how the influence not only individual men but also institutions, including fire agencies and their associated communication and education programs.

\section{Conclusions and avenues for future research}


It is argued here that the cultural construction and dominance of hegemonic masculinity in rural areas in Australia is likely to have played a role in the way individuals, couples and families understand and react to bushfire events. Notions of rural hegemonic masculinity may also help to explain the emphasis on the need to "stay and defend". While some research papers prior to Black Saturday claimed that actively defending a residence was likely to be the safest option in bushfire (e.g. Handmer \& Tibbits, 2005), these conclusions were heavily criticised during the Royal Commission for not taking into account people's varying levels of preparedness, physical abilities and emotional states (amongst other things). However, even if the options of staying to defend or leaving early are presented in a more equal manner, this fails to recognise the attraction of staying to defend in a context where fire-fighting, risk-taking, conquering nature, and defending family and home are all highly prized aspects of hegemonic rural masculinity. The "stay or go" policy was promoted by militarised and highly masculinised institutions in fire response and emergency services and, in effect, reinforced conditions where staying to defend was socially privileged over early evacuation, which was feminised.

Women and men involved in CFG groups prior to Black Saturday articulated this social pressure and the tension it often caused between male and female members of households, most prominently with women wanting to evacuate and men wanting to stay. However, many participants also noted that after the horrific events of these fires, there was a renewed push to accept "leaving early" as a viable and socially acceptable course of action. It is too early to state whether or not this change has had any long-term effect on how individuals, families and local communities prepare for, assess the risks of, and respond to bushfire events. Any change may be short lived if the social importance (particularly for men) of staying to defend and its ties to rural hegemonic masculinity are not addressed or acknowledged. What the findings presented 
here suggest, is that more research is needed in the area of gender and bushfire in order to better understand bushfire risk, preparedness and response but also to better understand the gendered dynamics of rural living in contemporary Australia. The concept of rural hegemonic masculinity and the emergence of possible alternative masculinities have been outlined here as a particularly promising ways of understanding not only certain behavioural aspects of bushfire preparedness and response at the household level but also as a way of understanding the broader cultural context to bushfire policy in Australia.

The existing international literature on gender and disaster offers ways forward and has rarely been mentioned in relation to bushfire policy or research in Australia. The gender and disaster literature, however, is still somewhat limited in that an analysis of masculinity and disaster to complement the vital work done on women's experiences of disaster, has not yet been fully developed. Therefore, the social science literature on the construction of gender, the relational nature of gender and, in particular, hegemonic masculinity and alternative masculinities, offer important ways forward for research in this area. The use of a social constructionist framework for understanding masculinity may therefore also provide broader avenues for international research on gender and disaster, in particular, an understanding of rural masculinities may help to provide a more nuanced understanding of how gender roles, identity and place influence disaster preparedness and response. 


\section{REFERENCES}

Agostino, K. (2003). Men, Identity and Military Culture. In M. Donaldson and S. Tomsen. (eds). Male Trouble: Looking at Australian Masculinities. Pluto Press, Melbourne.

Alston, M. (1995). Women in Rural Australia: A case for cultural misogyny. In P. Share (ed). Communication and Cultural in Rural Areas. Centre for Rural Social Research, Wagga Wagga: Aust.

Alston, M. (2005). Gender Perspectives in Australian Rural Community Life. In C. Cocklin and J. Dibden. (eds). Sustainability and Change in Rural Australia. University of New South Wales Press, Sydney.

Alston, M. (2006). The Gendered Impact of Drought. In B. Bock and S. Shortall. (eds). Rural Gender Relations: Issues and Case Studies. CABI Publishing, Cambridge: MA.

Ariyabandu, M. (2009). Sex, Gender and Gender Relations in Disasters. In E. Enarson \& P.G. Chakrabarti (eds). Women, Gender and Disaster: Global issues and initiatives. Sage Publications, London.

Bateman, J. and Edwards, B. (2002). Gender and Evacuation: A closer look at why women are more likely to evacuate for hurricanes. Natural Hazards Review, v3(3): 107-118. 
Beasley, C. (2008) 'Rethinking Hegemonic Masculinity in a Globalizing World', Men and Masculinities, 11(1): $86-103$.

Beaston, R. and McLennan, J. (2005). Australia's Women Volunteer Firefighters: A literature review and research agenda. Australian Journal of Volunteering, v10(2): 18-27.

Beaston, R. et al. (2008). Recruiting and Retaining Women Fire Service Volunteers. Fire Note. Bushfire CRC and AFAC: Melbourne.

Beaujot, R. and Liu, J. (2005). Models of Time Use in Paid and Unpaid Work. Journal of Family Issues, v 26(7): 924-946.

Beringer, J. (2000). Community Fire Safety at the Urban / Rural Interface: The bushfire risk. Fire Safety Journal, v35(1): 1-23.

Bolin, R. et al. (1998). Gender Inequality, Vulnerability and Disaster: Issues in theory and research. In E. Enarson \& H. Morrow (eds). The Gendered Terrain of Disaster: Through women's eyes. Praeger, Santa Barbara.

Bryant, L. and Pini, B. (2011). Gender and Rurality. Routledge: New York.

Cameron, P. et al. (2009) Black Saturday: The immediate impact of the February 2009 bushfires in Victoria, Australia. Medical Journal of Australia, v191(1): 11-16. 
Campbell, H. and Bell, M. (2000). The Question of Rural Masculinities. Rural Sociology, v65(4): 532-547.

Campbell, H. (2006). Introduction. In H. Campbell et al. (2006) (eds). Country Boys: Masculinity and rural life. Pennsylvania State University Press, University Park: PA.

Campbell, H. et al. (2006) (eds). Country Boys: Masculinity and rural life. Pennsylvania State University Press, University Park: PA.

Carrington, K. and Scott, J. (2008). Masculinity, Rurality and Violence. British Journal of Criminology, v48(4): 641-667.

Connell, R. (1995). Masculinities. University of California Press, Los Angeles.

Connell, R. (2005) Masculities, $2^{\text {nd }}$ Edition; Crows Nest, NSW: Allen and Unwin.

Connell, R. (2003). Introduction. In M. Donaldson and S. Tomsen, S. (eds). Male Trouble: Looking at Australian Masculinities. Pluto Press, Melbourne.

Connell, R. and Messerschmidt (2005) 'Hegemonic Masculinity: Rethinking the Concept', Gender and Society, 19(6): $829-59$.

Cox, H. (1998). Women in Bushfire Territory. In E. Enarson \& H. Morrow (eds). The Gendered Terrain of Disaster: Through women's eyes. Praeger, Santa Barbara. 
DeLaine, D. et al. (2008). "Fiery Women": Consulting, designing, delivering and evaluating pilot women's bushfire safety skills workshops. Paper presented at The International Bushfire Research Conference. Adelaide Convention Centre, Australia. $1^{\text {st }}-3^{\text {rd }}$ of September.

Dempsey, K. (1992). A Man's Town: Inequality between women and men in rural Australia. Oxford University Press, Melbourne.

Donaldson, M. and Tomsen, S. (2003). (eds). Male Trouble: Looking at Australian Masculinities. Pluto Press, Melbourne.

Enarson, E. (2009). Gendering Disaster Risk Reduction: 57 steps from words to action. In E. Enarson \& P.G. Chakrabarti (eds). Women, Gender and Disaster: Global issues and initiatives. Sage Publications, London.

Enarson, E. \& Chakrabarti, P.G. (eds). (2009). Women, Gender and Disaster: Global issues and initiatives. Sage Publications, London.

Enarson E. \& Morrow, H. (eds). (1998) The Gendered Terrain of Disaster: Through women's eyes. Praeger, Santa Barbara.

Enloe, C. (1983). Does Khaki Become You? The militarisation of women's lives. South End Press, Boston. 
Eriksen, C. et al. (2010). The Gendered Dimensions of Bushfire in Changing Rural Landscapes in Australia. Journal of Rural Studies, v26(4): 332-342.

Eriksen, C. and Gill, N. (2010). Bushfire and everyday life: Examining the awareness-action 'gap' in changing rural landscapes. Geoforum, v41(5): 814-825.

Fairbrother, P. et al. (2010). CFA Community Fireguard Review: Improving quality control and assurance. Centre for Governance, Work and Technologies, RMIT University. Melbourne: Aust.

Fairbrother, P. et al. (2012). Gender Matters: Applying a gendered analysis to bushfire research in Australia. Working Paper No. 3. The Centre for Sustainable Organisations and Work, RMIT University. Melbourne: Aust.

Finucane, M. et al. (2000). Gender, race and perceived risk: The "white male" effect. Health, Risk and Society, v2(2): 159-172.

Flood, M. (2002) 'Between Men and Masculinity: An Assessment of the Term "Masculinity" in Recent Scholarship on Men', in S. Pearce and V. Muller (Eds) Manning the Next Millenium: Studies in Masculinities, Bentley, WA: Black Swan Press, pp. $203-11$.

Fordham, M. \& Ketteridge, A. (1998). “Men Must Work and Women Must Weep": Examining gender stereotypes in disasters. In E. Enarson \& H. Morrow (eds). The Gendered Terrain of Disaster: Through women's eyes. Praeger, Santa Barbara. 
Fothergill, A. (1998). The Neglect of Gender in Disaster Work: An overview of the literature. In E. Enarson \& H. Morrow (eds). The Gendered Terrain of Disaster: Through women's eyes. Praeger, Santa Barbara.

Goodman, H \& Proudley, M. (2008) 'Social contexts of responses to bushfire threat: a case study of the Wangary fire.' In J. Handmer \& K. Haynes (eds.) Community Bushfire Safety, CSIRO Publishing, Australia.

Griffiths, T. (2012). The language of catastrophe: Forgetting, blaming and bursting into colour. Griffith Review, v35: 51-67.

Gustafson, P. (1998). Gender Differences in Risk Perception: Theoretical and Methodological Perspectives. Risk Analysis, v18(6): 805-811.

Handmer, J. \& Tibbits (2005). Is Staying at Home the Safest Option During Bushfires? Historical evidence for an Australian approach. Global Environmental Change Part B: Environmental Hazards, v 6(2): 81-91.

Handmer, J. et al. (2010). Review of fatalities in the February 7, 2009 Bushfires. Prepared for the Victorian Bushfires Royal Commission. Bushfire CRC, Melbourne. Available from: http://bushfirecrc.com.au/research/downloads/Review-of-fatalities-in-the-February-7.pdf (Accessed: 19/09/2010). 
Haynes, K. et al. (2010). Australian Bushfire Fatalities 1900-2008: Exploring trends in relation to the "prepare, stay and defend or leave early" policy. Environmental Science and Policy, v13(3): 185-194.

Hogg, R. \& Carrington, K. (2006). Policing the Rural Crisis. Federation Press, Sydney.

lacuone, D. (2005). "Real Men are Tough Guys": Hegemonic masculinity and safety in the construction industry. Journal of Men's Studies, v13(2): 247-253.

Laugharne, J. et al. (2011). After the Fire: The mental health consequences of fire disasters. Current Opinion in Psychiatry, v24(1): 72-77.

Maleta, Y. (2009). Playing with Fire: Gender at work and the Australian female cultural experience within rural firefighting. Journal of Sociology, v45(3): 291-306.

Masai, R. et al. (2009). Women in the Great Hanshin Earthquake. In E. Enarson \& P.G. Chakrabarti (eds). Women, Gender and Disaster: Global issues and initiatives. Sage Publications, London.

McCaffrey, S. \& Rhodes, A. (2009). Public Response to Wildfire: Is the Australian 'Stay and Defend or Leave Early' Approach an Option for Wildfire Management in the United States? Journal of Forestry, v107(1): 9-15. 
McFarlane, A.C. et al. (1997). Psychiatric Morbidity Following a Natural Disaster: An Australian bushfire. Social Psychiatry and Psychiatry Epidemiology, v32(2): 261-268.

McInnes, D. (2008) 'Sissy-boy Melancholy and the Educational Possibilities of Incoherence', in B. Davies (ed) Judith Butler in Conversations: Analysing the Texts and Talk of Everyday Life, New York: Routledge.

Meier-Pesti, K. and Penz, E. (2008). Sex or gender? Expanding the sex-based view by introducing masculinity and femininity as predictors of financial risk taking. Journal of Economic Psychology, V29(2): 180-196.

Mozumder, P. et al. (2008). Investigating Intended Evacuation from Wildfires in the WildlandUrban Interface: Application of a bivariate probit model. Forest Policy and Economics, v10(6): 415-423.

Murray, R. and White, K. (1995). State of Fire: A history of volunteer firefighting and the Country Fire Authority in Victoria. Hargreen Publishing, Melbourne.

Pease, B. (2001). Moving Beyond Mateship: Reconstructing Australian men's practices. In B. Pease and K. Pringle. (eds). A Man's World? Changing men's practices in a globalised world. Zed Books, London.

Pease. B. (2010). Reconstructing Violent Rural Masculinities: Responding to fractures in the rural gender order in Australia. Culture, Society and Masculinity, v2(2): 154-164. 
Pini, B.. (2006). A Critique of "New" Rural Local Governance: The case of gender in a rural Australian setting. Journal of Rural Studies, v(22)4: 396-408.

Poiner, G. (1990). The Good Old Rule: Gender and other power relationships in a rural community. Sydney University Press, Sydney.

Proudley, M. (2008). Fire, Families, Decisions. The Australian Journal of Emergency Management, 23(1): 37-43.

Robertson, D. (1998). Women in Emergency Management: An Australian perspective. In E. Enarson \& H. Morrow (eds). The Gendered Terrain of Disaster: Through women's eyes. Praeger, Santa Barbara.

Rush, J. (2009). A New Bushfire Safety Policy: Replacing the stay or go policy. Submissions of Counsel Assisting. Melbourne: Victorian Bushfires Royal Commission.

Scanlon, J. (1998). The Perspective of Gender: A missing element in disaster response. In E. Enarson \& H. Morrow (eds). The Gendered Terrain of Disaster: Through women's eyes. Praeger, Santa Barbara.

Scanlon, J. et al. (1996). The 1992 Peace River Ice Jam and Evacuation: An Alberta Town adapts to a sudden emergency. Emergency Communications Unit: Ottawa. 
Sheridan, G. (2009). Crisis survived, we must quickly apply the lessons. The Australian. $12^{\text {th }}$ February.

Shortall, S. (2006). Gender and Rural Politics: An overview. In B. Bock and S. Shortall. (eds). Rural Gender Relations: Issues and Case Studies. CABI Publishing, Cambridge: MA.

Teague B. McLeod R. and Pascoe S. (2010) Victorian Bushfire Royal Commission (2010) Final Report 'Summary', Government Printer for the State of Victoria.

Tibbits, A. \& Whittaker, J. (2007). Stay and Defend or Leave Early: Policy problems and experiences during the 2003 Victorian bushfires. Environmental Hazards, v7(4): 283-290.

Tierney, K. (2006). Social Inequality, Hazards, and Disasters. In: R. Daniels, D. Kettl and H. Kunreuther (eds) On Risk and Disaster: Lessons from Hurricane Katrina. University of Pennsylvania Press, Philadelphia.

Tyler, M. (2012) Gender, Inequality and Bushfire: Putting Australia in international context. Refereed paper presented at The Australian Sociological Association (TASA) Annual Conference. The University of Queensland, 26th - 29th November.

Väänänen. A. et al. (2004). The Double Burden of and Negative Spill-over Between Paid and Domestic Work. Women and Health, v40(3): 1-18.

Wendt, S. (2009). Domestic Violence in Rural Australia. Federation Press: Sydney. 
Zenaida, R. et al. Models of Earning and Caring: Determinants of the division of work. Canadian Review of Sociology, v46(4): 319-337.

Women's Health Golburn North East - WHGNE (2011). Beating the Flames: Women escaping and surviving Black Saturday. WHGNE: Wangaratta, Australia. Available from: www.whealth.com.au/documents/environmentaljustice/BeatingTheFlames-Book.pdf 


\section{DIAGRAM 1}
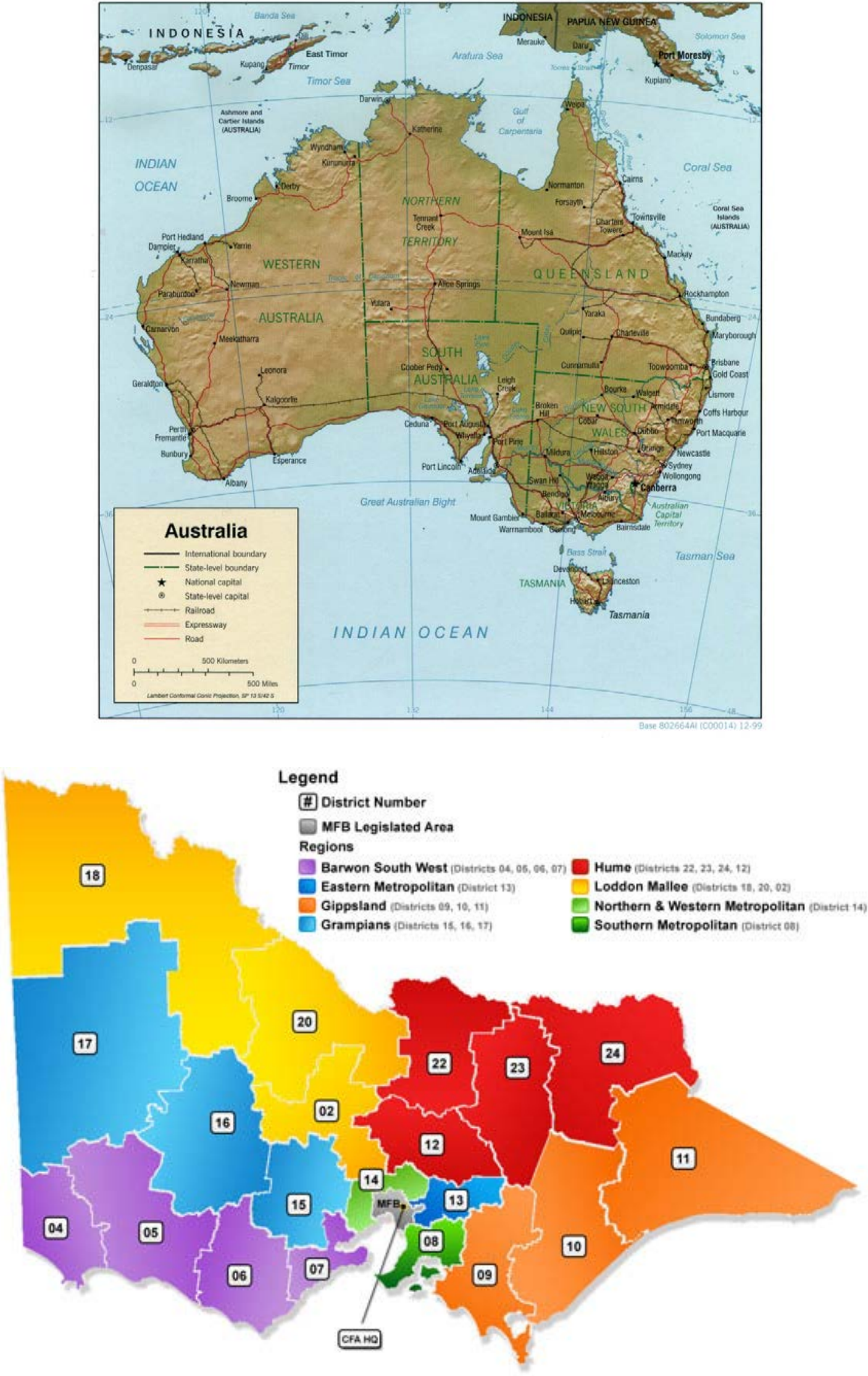

Australian map sourced through the University of Texas. Victorian map supplied through Country Fire Authority (CFA). 